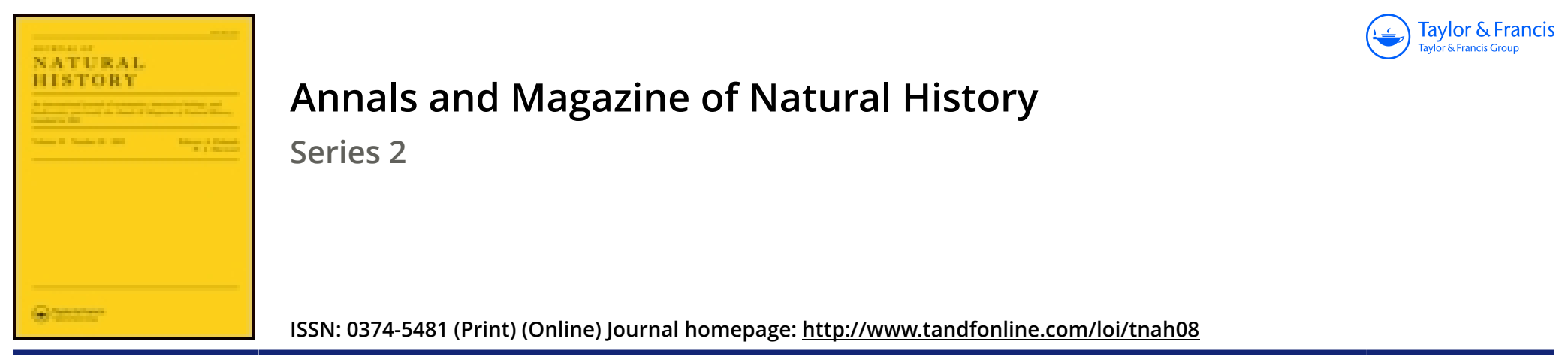

\title{
XXIV._-On fossil echinoderms from the Island of Malta; with notes on the stratigraphical distribution of the fossil organisms in the Maltese beds
}

\section{Thomas Wright M.D.}

To cite this article: Thomas Wright M.D. (1855) XXIV.-On fossil echinoderms from the Island of Malta; with notes on the stratigraphical distribution of the fossil organisms in the Maltese beds , Annals and Magazine of Natural History, 15:88, 262-277, DOI: 10.1080/037454809495418

To link to this article: http://dx.doi.org/10.1080/037454809495418

\section{Published online: 23 Dec 2009.}

Submit your article to this journal ए

\section{Џ Article views: 3}

Q View related articles ¿ 
XXIV.-On Fossil Echinoderms from the Island of Malta; with Notes on the stratigraphical distribution of the Fossil Organisms in the Waltese beds. By Thomas Wright, M.D. \&c., Professor of the Natural Sciences in the Cheltenham Grammar School.

[Concluded from p. 196.]

\section{Genus Schizaster (Agassiz, 1834).}

Urchins with a cordiform test, broad and depressed before, narrow and elevated behind; the ambulacral summit excentral and nearer the posterior border ; the petaloid ambulacra lodged in very deep depressions, the antero-lateral much longer than the postero-lateral pair ; the single ambulacrum long and deeply sunken in the anteal sulcus; the peripetal fasciole surrounds the ambulacral star, and from one of the antero-lateral angles thereof, a second postero-lateral fasciole arises, which passes downwards and backwards along the sides and under the anus, where it joins its fellow of the opposite side; the genital pores are two in number from the fusion of the anterior and posterior pairs ; the five ocular plates are small and lodged in depressions; the eye-holes are microscopic. Schizaster differs from Hemiaster in possessing a postero-lateral fasciole, and in having the anterolateral ambulacra less divergent and lodged in decper depressious; the anteal sulcus is also much deeper.

\section{Schizaster eurynotus, Agassiz.}

Syn. Echinus Spatangus compressus et lapidescens in Melitensi topho, Scilla, Corp. Mar. tab. 7. fig. 1.

Echimus gladiatus vestitus et nudus Imperati, Klein, Echinod. p. 35. tab. $27 \mathrm{~A}$.

Spatangus lacunosus, Leske, no. 77. p. 227.

Spatangus canaliferus, Lamarck, Anim. sans. Vert. 2nd ed.tom. iii. p. 327; Grateloup, Foss. Ours. Dax, p. $6 \%$.

Schizaster eurynotus, Sismouda, Mem. Echin. Foss. Nizza, tab. 2. fig. 3. p. 31 ; Agassiz and Desor, Ann. Sc. Nat. tom. viii. p. 21. série 3 .

Spatangus Scilla, Desmoulins, Etudes sur les Echin. no. 24. p. 392.

Test heart-shaped, depressed and rounded anteriorly, elevated and pointed posteriorly; ambulacral areas deeply excavated; the single ambulacrum long, deep, wider in the middle and narrower at the anterior border, which is deeply grooved by it : antero-laterals slightly $f$-shaped; angle $52^{\circ}$; length $1_{\frac{2}{2} 0}$ inch : postero-laterals, angle $72^{\circ}$, short, $\frac{7}{10}$ ths of an inch; apical disc with two genital holes near the posterior third; 
single interambulacrum elevated into a prominent carina terminating in a caudal hooked process.

Description.-This Urchin resembles Schizaster canaliferus now living on the shores of the Mediterranean, and for which it has been mistaken by some naturalists, but an attentive study of the living and fossil species discloses characters by which they may be distinguished from each other. The test in S. eurynotus is cordate, depressed before and elevated behind. The ambulacral areas are deeply depressed; the odd or anterior ambulacrum is nearly twice the width of the pairs, it swells out in the middle, is blunted at the apex, and most contracted at the anteal sulcus, which is deep and narrow when contrasted with the width it attains above. The poriferous zones lie at the base of the walls of the sulcus; the very narrow plates that compose the floor of this area are each studded with a row of small granules. The antero-lateral ambulacra diverge at an angle of $52^{\circ}$; they are slightly $f$-shaped, and are $1 \frac{5}{20}$ inch in length: the numbers of holes in the zones are thirty-six and thirty-four. The postero-lateral pair are short, and make an angle of $72^{\circ}$; they are $\frac{7}{1} \overline{0}$ ths of an inch in length, and have respectively twenty-six and twenty-four holes in their zones. The peripetal fasciole passes close to the base of the posterior pair, dips slightly into the space which separates the anterior from the posterior pair, runs at some distance from the anterior pair, passes close by the base thereof obliquely towards the anteal sulcus, into which it dips, and meets its fellow from the opposite side: the very narrow postero-lateral fasciole is directed obliquely downwards and backwards, and unites with its fellow at some distance below the anus. The test is depressed anteriorly and sloped away at the checks, whilst behind it is much elevated. The interambulacrum forms an elevated ridge between the posterior ambulacral pair, and is produced into a caudal-like process behind, beneath which the circular anus is pierced; the sternal portion of the odd interambulacrum is tumid and convex; the basal portions of the lateral and anterior pairs slope gently towards it; the tracks of the ambulacra are nearly naked as they approach the mouth, and are here perforated with buccal pores. The mouth is at the anterior third, and has a projecting underlip; the tubercles on the npper surface are small and of a uniform size; those on the sternum are larger, and are perforated and set on crenulated summits; they are arranged in lines radiating from a posteal point; the tubercles of the interambulacral pairs are the largest.

Affinities and differences.-This species very much resembles the living $S$. canaliferus, but it may be distinguished from it by 
the following characters:- $\boldsymbol{S}$. eurynotus is broader and more depressed before, and is not proportionally so high behind as S. canaliferus; the antero-lateral ambulacra are more divergent, and the postero-lateral pair are proportionally longer in S. eurynotus than in S. canaliferus. The single ambulacrum is about the same depth as the pairs, and has the pores in a single filc in S. eurynotus, whereas in S. canaliferus this area is much deeper, and the pores are not in single file, but are crowded together, so that they form three rows in a part of the zone; the tubercles of the base are much larger in the living than in the fossil species. $S$. eurynotus is distinguished from $S$. Parkinsoni by its $f$-shaped ambulacra being less divergent, and the position of the apical disc, which is much nearer the posterior border in $S$. curynotus; the anterior ambulacrum is likewise much wider and deepcr in that Urchin than in S. Parkinsoni: the great develop. ment of the single interambulacrum, and breadth of the posterior border in $S$. Desori sufficiently mark that species as widely distinct from S. eurynotus.

Locality and position.-Collected in bed No. 4, the calcareous sandstone at Malta ; we have it also from Santa Manza, Corsica, sent us by M. Michelin; it has likewise been found in the Ter. moyen de Perpignan, Cagliari.

\section{Schizaster Desori, Wright, n.sp. Pl. VI. fig. $3 a-c$.}

Test cordate, broxd and much depressed before, narrow and much elevated behind; ambulacral areas long, straight, and very divergent; peripetal fasciole forms an acute angle on the anterior interambulacra; apical disc situated at the posterior third of the dorsum; angle of the antero-lateral ambulacra $44^{\circ}$; angle of the postero-lateral pair $60^{\circ}$; posterior border truncated obliquely downwards and inwards ; sternal portion of the interambulacrum tumid and prominent at the base, amounting almost to a deformity.

Dimensions.-Antero-posterior diameter $2 \frac{8}{10}$ inches, transverse diameter $2 \frac{7}{7} 0$ inches, height at the deepest part $l_{\frac{8}{10}}$ inch.

Description.-This remarkable Urehin wants the symmetrical proportions of the other Schizasters met with in the same rocks ; it is rounded and broad before, and tapers into a narrow wedgeshape process behind ; the dorsal surface inclines forwards at an angle of $17^{\circ}$; the ambulacral areas are long. The single anterior area compared with $S$. eurynotus is narrow, and of a uniform width; it is $1_{\frac{3}{10}}^{3}$ inch in length from the apical disc to the fasciole; there are twenty-four pairs of pores in the avenues, the external being much larger than the internal row, although this is properly speaking a generic character. The antero-lateral 
ambulacra diverge nearly straight outwards at an angle of $14^{\circ}$; they form deep depressions in the test $l_{\frac{1}{10}}^{\frac{5}{0}}$ inch in length, and the zones contain thirty pairs of holes in each : the posterolaterals are shightly petaloid, and gently flexed outwards; they are $\frac{1}{2} \frac{5}{0}$ ths of an inch in length, and diverge at an angle of $60^{\circ}$. The zones contain about twenty pairs of holes; the test being nearly as broad as it is long across the termination of the antero-lateral ambulacra; the anterior border is gently rounded, and has a rather deep anteal sulcus for the ambulacrum; from the same point to the posterior extremity it tapers suddenly, which gives a wedge-shaped appearance to the test when viewed from above. The most remarkable feature in this Urchin is the curious form which the single interambulacrum assumes, owing to the great development of this area; the dorsal surface forms an inclined plane having an inclination of $17^{\circ}$; the anterior part is therefore very much depressed, and the posterior part much elevated. The single interambulacrum forms a prominent beaklike process, beneath which the posterior border is broad, and inclined downwards and forwards; the sternal portion of this area is prominent and convex, towards which the basal parts of the lateral interambulacra slope suddenly forwards and inwards. The anus is pyriform, and placed high up underneath the beaklike process. The moutl is situated near the anterior border; it has a large under-lip, but is crushed in the small specimen, and covered up in all the others before us. The small apical disc lies concealed at the posterior third of the dorsum by the prominent apices of the lateral interambulacra. The pcripetal fasciole takes a zigzag course along the outer borders of the ambulacra, and from the base of the antero-laterals it passes nearly at right angles across the anterior interambulacra to the external side of the single ambulacrum, where it makes another angle, then passes down the side thereof $\frac{3}{10}$ ths of an inch, dips into the sulcus and unites with the opposite fasciole. The lateral fasciole commences at the angle near the base of the antero-lateral ambulacra, and passes downwards and backwards nearly in a straight line over the angle of the posterior border at some distance from the anus, and meets the one from the opposite side, at the middle line near the base; in the triangle thus formed, the caudal process and anus occupy the base, and a depression lies beneath which is filled with tubercles somewhat larger than those on the dorsum, but smaller than those on the base; the tubercles are perforated and raised on prominent crenulated bosses (fig. $3 c$ ) ; the sternal and basal portions of the test, as well as the anterior border, being furnished with much larger tubercles.

Affinities and differences.-The straightness of the pairs of ambulacra, and the narrowness of the single anterior ambulacrum, 
are alone sufficient to distinguish S. Desori from S. purynotus when viewed only from above, but when we add to these the remarkable oblique truncation of the posterior border (fig. $3 b$ ), the great tumidity of the sternum, and the sloping character of the sides of the base, we discover how widely different these two forms are from each other. The same group of characters serves to distinguish it from S. Parkinsoni, but in this specics the apical disc is much nearer the centre of the test; the antero-lateral ambulacra are arched outwards, and the postero-laterals are proportionately longer.

Locality and stratigraphical position.-Collected from the calcareous sandstone bed No. 4, at Malta ; the large specimen belongs to the Bristol Institution, the others form part of Earl Ducie's collection. We dedicate this species to M. Desor of Neufchâtel, one of the learned authors of the 'Catalogue raisonné des Echinides.'

\section{Schizaster Parkinsoni, Defrance sp. Pl. V. fig. $3 a-c$.}

Srn. Spatangus Parkinsoni, Defrance, Dict. Sc. Nat. tom. 50. p. 96 ; Desmoulins, Etudes sur les Echinides, p. 394. no. 29.

Spatangus lacunosus, Parkinson, Organic Remains, vol. iii. tab. 3. fig. 12 .

Schizaster Parkinsoni, Agassiz and Desor, Cat. raisonné, Ann. Sc. Nat. tom. viii. p. 22.

Test cordate, depressed anteriorly, elevated posteriorly; apical disc nearly central; sides expanded and tumid; cheelis sloping and contracted; single ambulacrum rather wider than the anterior pair, of the same diameter throughout, except near the apex; antero-lateral ambulacra diverge at an angle of $35^{\circ}$; length 1 inch; postero-lateral make an angle of $65^{\circ}$; length $\frac{6}{10}$ ths of an inch; posterior part of the back raised into a long prominent carina; posterior border obliquely truncated ; base convex; mouth near the anterior border; anteal sulcus narrow and of moderate depth.

Dimensions. - Adult. Antero-posterior diameter $2 \frac{1}{2} \frac{3}{0}$ inches, transverse diameter $2 \frac{1}{2} \frac{1}{0}$ inches, height $1 \frac{1}{2} \frac{3}{0}$ inch.

Junior. Antero-posterior diameter 2 inches, transverse diameter $1 \frac{9}{10}$ inch, height $1 \frac{3}{10}$ inch.

Description.- We have identified this Urchin with that figured by Parkinson in his 'Organic Remains,' not however without much hesitation, inasmuch as that figure is without details, and is moreover drawn from a distorted specimen. We have in vain endeavoured to find out the original, and have therefore, from the central position of the apical dise and the great divergence of the ambulacra, and from its being at the same time the most 
common of all the Maltese Schizasters, and the one most likely to have been sent to Parkinson, adopted Defrance's identification. The test is heart-shaped, its widest part being at a line drawn across the disc; from this imaginary line the back slopes obliquely forwards, and the border is rather bevelled away at the cheeks ; from the same line backwards there rises a prominent ridge which bends over into a short tail-like process. The ambulacral areas $(3 a)$ are deeply sunken, the single ambulacrum has a tapering lanceolate form, and the anteal sulcus is deep and narrow; the poriferous zones lie in the angle of the depression; they consist of twenty-five pairs of holes, of which the outer series is the largest; the length of the petaloidal portion of this area from the apex to the fasciole is $1 \frac{1}{2} 0$ inch. The anterolateral ambulacra $(3 a)$ are more divergent in this species than in the other Schizasters met with in the same rocks; they are $1_{\frac{1}{2} \overline{0}}$ inch in length and are slightly curved outwards and backwards; they make an angle of $35^{\circ}$; the number of pores $(3 \mathrm{c})$ in the zones is respectively thirty-six and thirty-four, the apical eight pairs being almost microscopic: the postero-lateral pair are $\frac{6}{10}$ ths of an inch in length and slightly $f$-shaped; they are directed backwards at an angle of $65^{\circ}$, and are proportionately narrower than the anterior pair; there are twenty-two pairs of holes in each of the zones, the upper six pairs of which are microscopic. The peripetal fasciole $(3 b)$ is distinctly defined and passes close to the bases of the petaloid portions of the ambulacra, but at a short distance from the sides thereof it describes a curve inwards in passing over the anterior interambulacra, and dips obliquely into the anteal sulcus where it unites with that of the opposite side. The lateral fasciole is large and very distinct; it takes a backward and downward course towards the base of the posterior border, and joins its fellow at some distance be-low the anus; the two fascioles form the letter $V$ in their trajet on the test. The apical disc is situated very near the centre of the back, removed a little nearer to the posterior than the anterior border ; it is perforated with four equal-sized genital holes. The anus is oblong, situated high up in the obliquely truncated posterior border, in which is a triangular depression limited on the sides by the fasciole, and above by the anal opening and caudal process; the base is convex ; the sternum is not very prominent, and has lines of tubercles proceeding in radii from a point near the border ; the basal portions of the posterior ambulacra are naked, and around the mouth buccal pores are seen which extend at considerable intervals along the trajet of the posterior pair. The mouth is situated in the anterior fourth of the base and has a projecting under-lip; the basal parts of the interambulacra glide into the general convexity of the floor of 
the test; the lateral pair have a regular tuberculation, but on the anterior pair the tubercles are larger and more irregular.

Affinities and differences.-The nearly central position of the apical disc and the greater divergence of the antero-lateral ambulacra distinguish this Urchin from its congeners; the narrowness of the odd ambulacrum and the absence of the swelling-out in the centre of the same, serve to separate it from S. eurynotus; the blunt caudal process, the small posterior border, and the general tumidity of the sides distinguish it from S. Desori.

Locality and stratigraphical position.-Collected from bed No. 4, the calcareous sandstone at Malta, where it is common; it is found likewise in the Molasse, middle tertiaries, of Martigues, Bouches-du-Rhone. Fine specimens are contained in the British Museum, Jermyn Street Muscum, and that of the Bristol Institution.

Since the preceding sheets of this memoir have been passing through the press, we have had the opportunity of examining the Maltese fossils belonging to the Geological Socicty, and some that had escaped our notice in the British Museum collection; from these new materials the following notes are now added :-

\section{Clypeaster Reidii, Wright, n. sp.}

Test large, broadly pentagonal, and much elevated; border abrupt, margin thin and undulated, rising with steep sides at angles of $60^{\circ}$, and with a very little curve towards the vertex, which is nearly central ; petaloidal portions of the ambulacral areas large, nearly equal in width, and extending over nearly three-fourths of the sides; base quite flat; mouth small, pentagonal, nearly central; basal ambulacral sulci proceeding: from the angles of the mouth, narrow, and sharply defined; anus round, near the posterior margin; tubercles on the upper surface small and closely set together, those on the base a little larger; apical disc nearly central and prominent, with an outer circle of genital holes, and an inner circle of eyeholes having the madreporiform tubercle in the centre.

Dimensions. - Antero-posterior diameter $5 \frac{6}{10}$ inches, transverse diameter $5 \frac{2}{10}$ inches, height $2 \frac{8}{10}$ inches.

Description.-This large Clypeaster has been mistaken for one of the varieties of $C$. altus, but a careful study of its test discloses characters by which it is readily distinguished from that common form. The circumference is nearly pentagonal; it is rounded before, undulated on the sides, and nearly straight behind; the sides of the pentagon are of unequal length, those forming the front of the test are the shortest, those of the 
middle are somewhat longer, and the posterior single side is the longest. There is scarcely any margin to the test in this species, as the sides rise abruptly from the border to the apex, making angles of $60^{\circ}$ with the base, and being only slightly curved inwards; the dorsum is therefore very small in proportion to the diameter of the base. The petaloidal portions of the ambulacral areas extend over nearly three-fourths of the sides; they form long elegantly-shaped petals, narrower in proportion to their length than those of $C$. altus, and consequently allowing of a greater development of the interambulacral areas than in that species; the petaloidal ambulacral areas are nearly all of the same length, width and structure; the centre of each petal is arched and costated, and forms a considerable relief on the surface of the test. The poriferous zones lie in slight depressions on their sides ; each zone contains sixty-two pairs of pores set widely apart; in the inner row the holes are round, in the outer row they are oblong, and both are united by straight oblique sulci; the external surface of the partition-wall between each pair is covered with a row of small tubercles. The bases of the ambulacra are open, but not so widely as in some other congeneric forms. The interambulacral areas are nearly flat, of moderate width, and very uniform in their structure. The apical disc occupies the centre of the dorsal surface; it consists of two circles of holes; the outer is formed of five small genital holes, the plates of which are not distinguishable, and the inner of five small perforated ocular plates, which are distinctly visible at the apices of the ambulacra. The madreporiform tubercle occupies the centre, and forms a button-like prominence there; the border is thin and undulated, and this portion of the test presents a striking difference to the obtuse marginal fold seen in $C$. ultus. The base is quite flat; the pentagonal mouth is small and nearly central; the oral lobes are curved inwards at an acute angle, and the five ambulacral sulci are sharply defined as they radiate from the sides of the pentagon to the border. The anus is round, and is situated near the posterior border : the tubercles on the upper surface are small and closely set together; those on the base are a little larger.

Affinities and differences.-Clypeaster Reidii very much resembles C. umbrella both as to height, width, and the smallness of its tubercles ; it is distinguished from that species by the following characters : C. Reidii is more elongated; the petaloidal ambulacra are longer and narrower; the interambulacra are flattened and slightly curved; the base is quite flat, and the oral lobes are curved acutely inwards. In C. umbrella the interambulacra are arched and costated, the base is concave, and the oral lobes slope obliquely inwards. Compared with C.altus, the 
differences are found to be still greater: in $C$. Reidii the test is broader in proportion to its length; the petaloid ambulacra are narrower; the poriferous zones are not so open at the base. The apical disc is convex and prominent in $C$. Reinlii, and depressed in $C$. altus. In $C$. Reidii the border is thin and sharp, and the base is flat. In C. altus the border is thick and rounded, and the base is concave. In $C$. Reidii the mouth is small, and the oral lobes curve acutely inwards; whilst in C. altus the large mouth lies at the bottom of a concave depression formed by the gradual inward sloping of the interambulacra. The distinctions between our species and that of $C$. scutellatus and C. marginatus are so well defined, that it is unnecessary to make a comparison with them.

Locality and stratigraphical position.-This species is apparently from bed No. 1, the Gozo marble, but this we cannot with certainty state. Fine specimens are in the Jermyn Street Museum, and in the collection of the Geological Society of London. We dedicate this species to his Excellency Sir William Reid, Governor of Malta, whose laudable efforts to form a public collection of Maltese fossils have greatly contributed to our knowledge of the palæontology of the island.

\section{Genus Pygorhynchus, Agassiz, 1839.}

In the dismemberment of the genus Nuclealites of Lamarck, M. Agassiz has not been so fortunate as in other groups of Echinida: the characters on which, for example, Catopygus and Pygorhynchus are distinguished from Nucleolites are not satisfactory, as they undergo important modifications in the different species grouped together in each of these new genera. If we take a type specimen of each genus only and compare them together, we admit the distinctions pointed out; but when we examine several species of each of these genera, we observe the characters gradually blending into the primary type form: as representatives in time, the grouping is valuable, but the zoological characters in our judgment are too indefinite to found genera thereon. With these remarks we refer provisionally the small Nucleolite before us to the section Pygorhynchus, which is thus characterized by Agassiz:-- " Form elongated; ambulacra distinctly petaloid, often costated as in Echinolampas. Mouth central or subcentral, pentagonal, surrounded with five large lobes, and a distinct resette of buccal pores. Anus posterior, nearer the superior than the inferior border." All the species of the genus Pygorhynchus belong to the nummulitic and tertiary rocks; those of the genus Catopygus, with one exception, are cretaceous forms. 


\section{Pygorhynchus Vassalli, Wright, n. sp.}

Test oblong, wider behind than before; interambulacrum produced into a caudal elongation; petaloid portions of the ambulacral areas narrow and short; sides tumid; anus small, round, nearer the inferior border than the dorsum, with a projecting beak-like process arching over its upper border, and an oblique truncature of the lower part of the border below ; base slightly concave; mouth pentagonal, nearly central; oral lobes small; rays of the poriferous star around the margin short.

Dimensions.-Antero-posterior diameter $1 \frac{3}{20}$ inch, transverse diameter $\frac{7}{10}$ ths of an inch, height nearly $\frac{6}{10}$ ths of an inch. Most of the specimens average only from one-half to two-thirds of these dimensions. The large specimen before us is the most perfect we have examined.

Description.-This small Urchin has an oblong form; it is rounded before, a little enlarged towards the junction of the middle with the posterior third, which is produced into a caudal process. The sides are tumid, and the upper surface is flattened; the petaloid portions of the ambulacral areas are narrow and short, and form only a star on the dorsum; the single and postero-lateral areas are nearly alike in width and length; the antero-lateral pair are rather wider and shorter, they are $\frac{7}{20}$ ths of an inch in length, and are slightly curved forwards and outwards; their poriferous zones contain eighteen pairs of pores, arranged in narrow rows, and not united by any apparent slit. The postero-lateral areas are $\frac{8}{20}$ ths of an inch in length, and their zones contain twenty pairs of pores; these areas are directed much backwards, which makes the width of the lateral interambulacra proportionally greater. The apical disc is nearly central, but nearer the anterior border; it has four large genital pores, and five well-marked eye-holes. The single ambulacrum is almost identical in length and width with the posterior pair; the apices of all the ambulacra are rather rounded than lanceolate. The lateral interambulacra we have said are very wide, but the single interambulacrum is narrow, and forms a conspicuous prolongation or beak-like process, which arches over the upper border of the round anal opening, situated rather below the middle of the posterior border, in an oblique truncature of the test: this beak-like process is not seen in the small specimens before us; it would therefore appear to be a character of the aclult condition only. The base is slightly concave towards the mouth, which is situated nearer the anterior border; it has a pentagonal form, with five small oral lobes covered with tubercles; between them, the terminations of the ambulacra form five short pori- 
ferous petals. The tubercles on the upper surface are small and irregularly disposed on the plates; those on the base are a little larger, especially in the vicinity of the mouth.

Affinities and differences.-This species resembles Catopyyus fenestratus from the upper chalk of Ciply, Belgium, but is distinguished from it by having the sides more tumid and the upper surface flatter; the posterior border is likewise more produced; it distinctly differs from it however in having the base slightly concave, and the oral lobes less developed. It difiers from Nucleolites (Pygorhynchus) subcarinatus, Goldf., from the middle tertiaries of Bünde, in having more tumid sides, a less concave base, and a different form of the anal opening. From the very brief notice of Catopygus conformis, Desor, from the tertiaries of Orglande, it is impossible to form any idea how far it may resemble that form, as it is neither figured nor described, but merely entered in the 'Catalogue raisonne' with this remark: "Mais l'anus est un peu plus bas, et la face supérieure plus surbaissée."

Locality and stratigraphical pasition.-Collected from bed No. 1, Malta, where it is extremely rare. Specimens are in the collection of the Geological Society, the Jermyn Street Museum, and the cabinet of Larl Ducie. We dedicate this species to Dr. Vassallo of Malta, under whose judicious care and continued research the public collection of Maltese fossils has been greatly euriched.

\section{Spatangus Desmarestii, Goldf.}

Syn. Spatangus Desmarestii, Goldf. Petref. p. 153. tab, 47. fig. $4 a-c$; Agassiz and Desor, Cat. raisonné, Ann. Sc. Nat. tom. viii. p. 7 .

Test cordate, arched and carinated; anteal sulcus broad; petaloid portion of the antero-lateral ambulacra long, narrow, and curved outwards and a little backwards, angle of inclination $18^{\circ}$; postero-laterals long and narrow, angle $60^{\circ}$; only a few moderate-sized tubercles on the interambulacral plates between all the ambulacral areas; border slightly obtuse; posterior part truncated ; anal opening transversely oblong; base planoconvex ; tubercles moderate in size; mouth transversely oblong, situated at the junction of the anterior with the middle third; tubercles on the upper surface very small.

Dimensions.-A German type specimen. Antero-posterior diameter $2 \frac{7}{10}$ inches, transverse diameter $2 \frac{6}{10}$ inches, licight $1 \frac{6}{10}$ inch.

A Maltese specimen. Antero-posterior diameter $1 \frac{8}{10}$ inch, transverse diameter $1 \frac{7}{10}$ inch, height $\frac{1}{2} \frac{7}{0}$ ths of an inch.

Description. - This Urchin is well known from the admirable figure in Goldfuss. Its upper surface is more convex and in- 
flated than in the other congeneric species; it is higher behind than before, and has a blunt ridge which passes backwards from the disc to the border. The antero-lateral petaloidal ambulacra, $\frac{1}{2} \frac{9}{0}$ ths of an inch in length, curve a little outwards, forming an angle of $18^{\circ}$; their zones contain from twenty-two to twentyfour pairs of pores, separated by rather thick partitions of the test. The postero-lateral areas are narrower than the anterior pair, and rather more than an inch in length ; their zones contain from twenty-eight to thirty pairs of holes, and they form angles of $60^{\circ}$. The interambulacral areas are wide and largely developed in this species; the upper plates in these areas, lying between the ambulacra, support only very small perforated tubercles, arranged in groups of threes and fours, and disposed on all the areas; this character serves to distinguish S. Desmarestii from all its congeners at present known: the small tubercles on the dorsal surface are very small, and closely set together. The single ambulacrum is lodged in a broad shallow valley, which forms however a considerable anteal sulcus; the pores in this area are so much covered up with matrix in our specimen, that we are unable to count their number. The posterior border is truncated, and the large transversely oval anal opening occupies the upper part of this region. The shelly matrix entirely conceals the course of the subanal fasciole. The sternal portion of the interambulacrum is slightly convex, and covered with small tubercles that radiate in lines in all directions from a central point; the basal portions of the anterior and lateral interambulacra are covered with larger tubercles, and the naked intermediate spaces indicate the trajet of the basal portions of the postero-lateral ambulacra from the border to the mouth. The mouth is situated at the junction of the anterior with the middle third; it is much elongated transversely, and has five poriferous petals surrounding it. The apical disc is small and nearly central; it has four genital holes and five small eye-holes.

Affinities and differences.-The inflation of the test, the smallness of the large tubercles on the upper surface, and their presence on the interambulacrum, serve to distinguish this species from its congener's.

Locality and stratigraphical position.-Found with S. Hofmanni in bed No. 4, the calcareous sandstone at Malta, where it is rare. The Maltese specimens we have seen are small, and do not exceed the dimensions given; they are contained in the collections of the British Museum and the Geological Society. In Germany it is found in the middle tertiaries at "Duberge bei Bünde, and at Astrupp bei Osnabrück." The admirable figure given by Goldfuss of this species is all that can be desired.

Ann. \& Mag. N. Hist. Ser. 2. Vol.xv. 
Genus Evpatagus, Agassiz, 1847.

Spatangoid Urchins, with a cordate or elliptical form, more or less depressed ; the petaloid portions of the antero- and posterolateral ambulacral areas are wide; the single area is lodged in a shallow anteal sulcus, and the entire ambulacral star is closely surrounded by a broad well-defined peripetal fasciole, which undulates round its margin; within this fasciolar space, the interambulacral plates carry very large perforated tubercles raised on crenulated bosses, and surrounded by wide smooth areolas, like those in the genus Spatangus. The heart-shaped shield, beneath the anal opening, is likewise surrounded by a welldefined subanal fasciole. The basal portions of the posterolateral ambulacra form broad, naked bands, between the posterior border and the mouth. The other characters resemble those of Spatangus, from which it differs however in possessing a peripetal fasciole.

Eupatagus De Koninckii, Wright, n. sp.

Syn. Spatangus De Koninckii, Wright, Ann. of Nat. Hist. vol. xv. p. 178.

The test of the original specimen of Eupatagus De Koninckii having had the external layer of its shell and consequently its fascioles denuded, we are now enabled to correct our determination of this species from a specimen in the collection of the British Museum, in which these important parts of the anatomy of the skeleton are well preserved. For the description of this Urchin see our article Spatangus De Koninckii, to which we subjoin the following note:-The peripetal fasciole is rather broad, surrounding with little undulation the ambulacral star, and forming a well-defined boundary between that portion of the upper surface with large perforated tubercles, and that part with very small tubercles; the subanal fasciole heart-shaped, rather broad, and enclosing a shield-like space filled with larger tubercles; it extends from the prominent point of the base to near the lower part of the anal opening.

Scalaria Duciei, Wright, n. sp. Pl. VII. fig. $4 a, b$.

Diagnosis.-Shell turriculated, imperforate ; spire gently tapering; whorls ten, with transverse prominent plates and longitudinal elevations. The transverse plates, nineteen in number on the body-whorl, are formed of numerous thin shelly laminæ, closely united where they proceed from the whorl, but outwardly they expand and form a rather irregular undulated surface; each plate describes three curves; two of these, the 
anterior and posterior, are short, and the central one is long, forming an arch over the whorl; the posterior, at their junction with the central curve, form angles, from whence blunt spiny processes proceed; these form a conspicuous ridge on the posterior upper part of the whorls; the junction of the anterior with the central curves forms a carina on the bodywhorl, which commences at the posterior border of the aperture, and terminates at the anterior part thereof, at a distance from the umbilical ridge. The longitudinal elevations form a kind of cellular structure; between the plates they are seven or eight in number, and on them and the intervening surface of the shell, delicate longitudinal lines are sculptured. The aperture is entire, and is round or inclining to an oblong.

Dimensions. - Length $2 \frac{2}{10}$ inches, diameter of the body-whorl $\frac{1}{2} \frac{5}{0}$ ths of an inch.

Collected from the calcareous sandstone No. 4, at Malta.

Lenticulites complanatus, Defrance. PI. VII. fig. $4 a, b$.

Genus Lenticulites, Lamarck. (Subkingdom Radiata. Class Foraminifera. Order Hélicostègues, D'Orb. Family Nautiloida.)-Shell nautiloid, equilateral, spire rolled on the same plane, compressed, sublenticular, multilocular ; whorls apparent, opening narrow, triangular, prominent, against the penultimate turn of the spire.

Diagnosis._Shell oblong, lenticular, much compressed; septa convex, with longitudinal partitions, growth lines very apparent. Long diameter $\frac{4}{10}$ ths of an inch.

This beautiful Foraminiferous shell occurs in great abundance in No. 2, the yellow sand with blackish grains; in fact it forms large masses of rock in this bed. As it is constantly associated with the Echinoderms, we have added a drawing thereof. Defrance noticed, but did not figure this fossil; he collected it at "Anvers près de Pontoise, à Dax, à Loignan près de Bordeaux, à Boutonnet près de Montpellier, et en Italie dans les couches, qui paroissent appartenir au calcaire coquillier grossier*."

EXPLANATION OF PLATES IV. V. VI. AND VII.

\section{Plate IV.}

Fig. 1. Cidaris Melitensis : $a$, the upper surface; $b$, side view of the ambulacral and interambulacral areas, natural size; $c$, an interambulacral plate, and a portion of an ambulacral area with the poriferous zones, magnified.

* Dict. Sc. Nat. tome xxv. p. 453. 
Fig. 2. Echinus Duciei : $a$, upper surface ; $b$, side view, natural size ; $c$, the form of the mouth-opening, showing the disposition of the marginal notches ; $d$, the five jaws and teeth " in situ," imbedded in a mass of rock; $e$, the apical disc, showing the arrangement of the genital and ocular plates; $f$, two interambulacral plates, and a portion of a poriferous zone, magnified.

Fig. 3. Echinolampas Deshayesii : $a$, the upper surface; $b$, the under surface, natural size ; $c$, a portion of the test, showing the tubercles, magnified; $d$, a portion of an ambulacral area, and poriferous zones, magnified.

\section{Plate V.}

Fig. 1. Brissus latus: $a$, the dorsal surface, reduced one-third in size; $b$, the apical disc, magnified; $c$, the perforated tubercles, with their crenulated bosses and encireling granules, magnified.

Fig. 2. Brissus oblongus: $a$, the upper surface, showing the petaloid ambulacral star and peripetal fasciole; $b$, the under surface, showing the subanal fasciole, natural size; mouth, and the trajet of the naked basal portions of the ambulacra; $c$, the tubercles, and their circles of granules, magnified.

Fig. 3. Schizaster Parkinsoni : a, the upper surface, showing the petaloid ambulacral star, the peripetal and lateral fascioles, the natural size; $b$, a portion of the peripetal fasciole, with the boundary granules, magnified; $c$, a portion of the poriferous zones, magnified.

\section{Plate VI.}

Fig. 1. Brissopsis Duciei : a, the upper surface, showing the petaloidal ambulacral star, surrounded by the peripetal fasciole, reduced one-third; $b$, six plates with small poriferous tubercles from the anteal sulcus ; $c$, form of the pores, and arrangement of the tubercles in the poriferous zones; $d$, the larger perforated tubercles, and their crenulated bosses with their circlets of granules; $e$, a portion of the peripetal fasciole, showing how distinctly it is defined from the rest of the surface by rows of granules.

Fig. 2. Brissopsis crescenticus : $a$, the upper surface; $b$, the under surface, natural size; $c$, the arrangement of the pores, near the apical portion of one of the zones.

Fig. 3. Schizaster Desori: $a$, the upper surface; $b$, the under surface, natural size; $c$, the perforated tubercles, with their circlets of granules and crenulated bosses, magnified.

\section{Plate Vil.}

Fig. 1. Hemiaster Scille: a, the upper surface, showing the ambulacral star and peripetal fasciole, natural size; $b$, the under surface of the same test ; $c$, a lateral view, to show the great height of this species; $d$, the perforated tubercles and encircling granules, magnified; $e$, a portion of the single ambulacrum, showing the arrangement of the pores; $f$, a portion of a poriferous zone.

Fig. 2. Hemiaster Cotteauii: $a$, the upper surface, natural size; $b$, the perforated tubercles, with their circles of granules; $c$, portion of a poriferous zone; $d$, portion of the peripetal fasciole, with its boundary granules.

Fig. 3. Scalaria Duciei: $a$, shell, the natural size; $b$, a fragment showing the mouth. 
Fig. 4. Lenticulites complanatus : a, natural size of this Foraminiferous shell; $b$, a section magnified, showing the cells:-large rocky masses of this fossil occur in the yellow sand associated with the Urchins of that deposit.

XXV.—On Monopus medusicola, a species of Leech. By Philip Henry Gosse, A.L.S.

[With a Plate.]

IN my 'Devonshire Coast' (p. 359) I have mentioned the occurrence of a small Leech parasitic on the Medusa, Willsia stellata.

As I have not been able to assign it to any recognized genus of the Hirudinidee, I will here repeat the characters, give a figure of it, and appropriate to it a name. Though the note and the drawing taken of it at the time, are not so detailed as I could have wished them to be, yet as I can answer for their accuracy so far as they go, they will at least serve to identify the form, should it occur again.

\section{Monopus (mihi).}

Body soft, subcylindrical, depressed; anterior sucker imperfect; posterior a circular disk, at the extremity of a short thick truncate column, distant one-third of the total length from the anal extremity, on the ventral side. Anterior extremity obtuse; posterior briefly attenuate. Eyes eight, set around the frontal margin of the anterior disk. Intestinal canal straight, simple; anus terminal.

\section{Monopus medusicola (mihi).}

Less than 1 line in length; pellucid : eyes hyaline : parasitic on Medusæ.

The ovary was ample, and contained a number of clear, globular, highly refractile ova, variously grouped, in the posterior moiety of the abdomen. Close-set transverse annuli surrounded the anterior portion. The intestinal canal had two fusiform swellings, and was enveloped near the cesophagus with opake cloudy matter.

The generic name was suggested by the foot-like appearance of the posterior sucker.

\section{EXPLANATION OF PLATE VIII. B.}

Fig. a. represents Monopus medusicola, ventral surface.

Fig. $b$. the same, laterally.

58 Huntingdon Street, Barnsbury Park, March 5, 1855. 